\title{
Removal of chemical and microbial contaminants from greywater using a
} novel constructed wetland: GROW

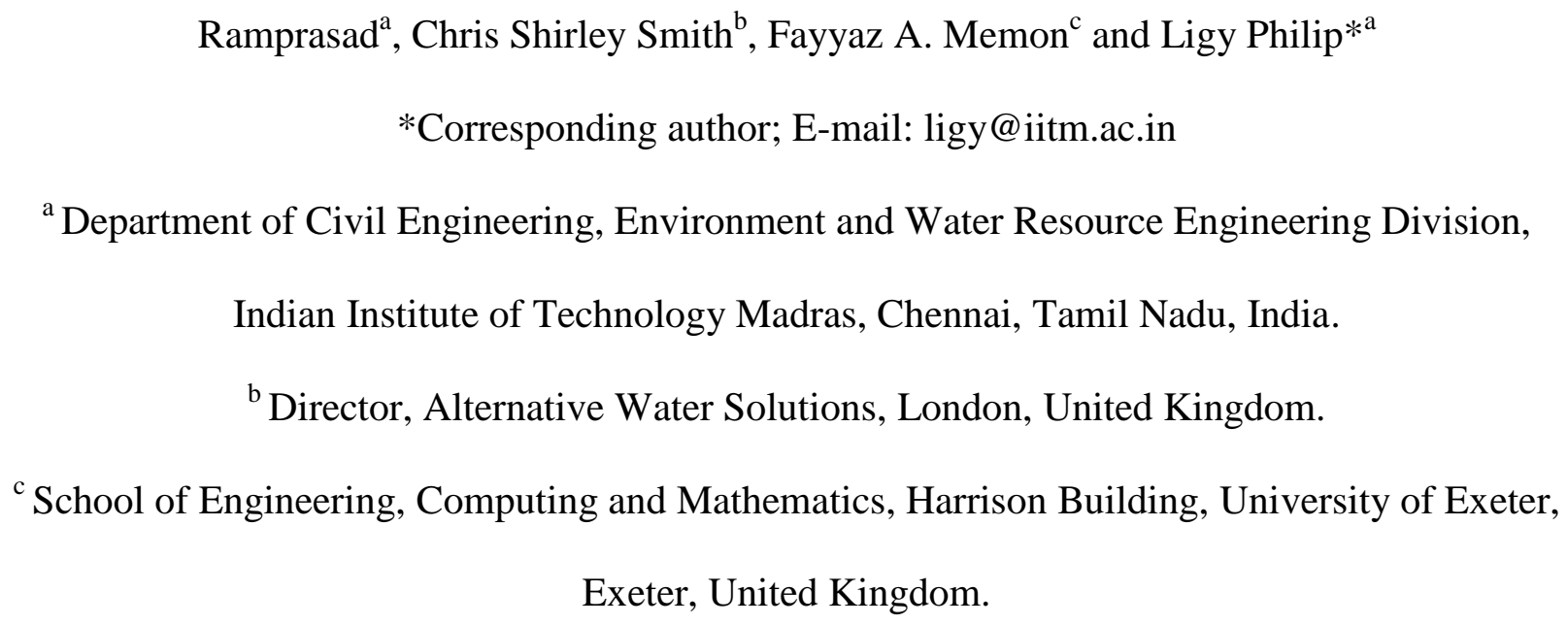
Indian Institute of Technology Madras, Chennai, Tamil Nadu, India.

${ }^{\mathrm{b}}$ Director, Alternative Water Solutions, London, United Kingdom.

${ }^{\mathrm{c}}$ School of Engineering, Computing and Mathematics, Harrison Building, University of Exeter, Exeter, United Kingdom.

\section{Abstract:}

The availability of freshwater resources is becoming universally depleted, leading to the requirement for a focused management strategy for treating and reusing wastewater. In particular for urban and developing areas, small scale decentralized treatment systems are becoming popular. The GROW (Green Roof-top Water Recycling System) constructed wetland is one such option that provides a solution without a permanent land requirement and offering medium to high treatment efficiency. The performance of the GROW system was monitored from November 2013 to April 2015 in treating greywater from the Krishna Student Hostel in IIT Madras. The performance of the GROW wetland cells were examined over four monitoring periods in Phase 1 namely: 1) start-up stage, 2) seasonal variation 3) change of flow rate and 4) change in organic fraction $(26.8,25.9$ and $25.5 \mathrm{~g} \mathrm{COD} /$ cubic. meter/ day respectively). In Phase 2 , the plants and the filling materials were changed and the performance of GROW wetland cells were evaluated. The system was fed with greywater at a flow rate of 62, 70, 82, 100 and $120 \mathrm{~L} /$ day respectively with hydraulic retention time of $0.7-1.3$ days. The samples taken from the inlet 
24 and the outlets of the GROW system were taken weekly and analyzed for the following 25 parameters; $\mathrm{pH}, \mathrm{COD}, \mathrm{BOD}, \mathrm{TSS}, \mathrm{TN}, \mathrm{NO}_{3}-\mathrm{N}, \mathrm{TP}, \mathrm{FC}, \mathrm{SDS}, \mathrm{PG}$ and TMA. In the study, the 26 overall removal efficiency was greater than $82 \%$ for all the parameters. The GROW wetlands 27 reduced all the above mentioned parameters to within or closely to the USEPA standard limits 28 for reuse. The reusable effluent water is named 'Green Water'.

Keywords:

Constructed wetland, Greywater, Recycle, Surfactants and Personal care products, Nutrients,

\section{Organics}

\section{Introduction:}

Increasing stress on the availability of freshwater sources worldwide has forced water providers

to develop wastewater management strategies giving emphasis for recycling and reuse of treated

37 wastewater. Wastewaters from households are classified into two types, i.e., i) greywater and ii)

black water. Greywater includes wastes generated from bathroom sinks, baths or showers,

39 washing clothes and possibly dishwasher except the wastewater from toilet whereas black water

is the wastewater generated from toilets. Wastewater from dishwashers is usually excluded from

41 greywater, due to high loading of fats/oils/ greases (FOGs), organic content and bacterial

42 contamination, which makes the wastewater difficult to degrade and handle (Jefferson et al.,

43 2000; Avery et al., 2007). Greywater treatment and reuse is one of the efficient solutions which

44 offer the largest potential of water savings, accounting for 50-80\% of freshwater water 45 consumption (Eriksson et al., 2002; Gross et al., 2007) in domestic purposes. Moreover, 46 greywater is lightly polluted and requires less expensive treatment prior to non-potable reuse 
47 (Jefferson et al., 2000; Avery et al., 2007). There are various technologies available for treatment

48 of greywater such as activated sludge process (ASP), membrane bioreactors (MBR), sequential

49 batch reactor (SBR), rotating biological contractor (RBC), photocatalysis and electro coagulation

50 (Merz et al., 2007; Masi et al., 2010). However, capital/infrastructure cost, social acceptance and

51 power requirement may limit their application in rural and peri-urban areas in developing

52 countries.

54 Treatment and reuse of greywater (as 'Green Water') for non-potable/secondary applications 55 using various low cost less land intensive, sustainable and efficient technologies have been 56 carried out in the past. The greywater was treated using a novel organic cation octadecyl 57 trimethyl ammonium (ODTMA) with montmorillonite as a filtration unit along with a moving complex was efficient in purifying GW due to its large surface area, positive charge and existence of hydrophobic domains (Rakovitsky et al., 2016). Another study uses an anaerobic filter followed by ultraviolet disinfection system for the treatment and reuse of greywater from an airport in Brazil (Do Couto et al., 2015). In-order to improve the green area of the city and to treat domestic greywater through a shallow horizontal subsurface constructed wetland that can be located in a household roof. A Wetland roof (WR) system was developed by Thanh et al. (2014), the system achieved an average COD removal efficiency of $77-78 \%$ or $20-28 \mathrm{~kg}$ COD/ha $\mathrm{d}$ for both sunny and rainy days. The system was able to remove nutrients also effectively with a TN removal efficiency of $88-91 \%$ or $17-20 \mathrm{~kg}$ TN/ha d, and a TP removal efficiency of $72-78 \%$ or $1.6 \mathrm{~kg} \mathrm{TP} / \mathrm{ha} \mathrm{d}$ for different HLRs. A pilot installation of a green wall treating greywater from an office building in Pune, Maharashtra State, India. Green walls were filled with LECA ${ }^{\circledR}$ 
70 (lightweight expanded clay aggregate) and coconut fibers. COD removal efficiency of this 71 system was in the order of 14-86\% (Masi et al., 2016).

72

73 Constructed wetlands $(\mathrm{CW})$ are also one of such systems considered as sustainable, cost effective

74 and a viable treatment option for treating greywater for small communities. Over the past few

75 years, CW has gained popularity due to its effectiveness, low capital investment and low cost of 76 operation with less maintenance over the conventional systems for treating various types of 77 wastewaters such as municipal wastewater, textile effluent and landfill leachate (Masi et al., 78 2010). The earlier researches are mainly focused only on the treatment of real-time greywater 79 using CWs for the overall removal of organics, nutrients and pathogens (Avery et al., 2007; 80 Gross et al., 2007; Frazer Williams et al., 2008; Winward et al., 2008). But the present study 81 focuses on the performance of novel constructed wetland (GROW) under various operating 82 conditions (start-up, seasonal, hydraulic loading rate and organic loading rate) in treatment of 83 real-time greywater. Additionally, the current study also focuses on the removal of surfactants 84 and personal care products (SDS, PG and TMA) from real time greywater using GROW system. 85

86 There are various types of constructed wetland classified based on their flow pattern;

87 i) Horizontal subsurface flow constructed wetland, ii) Vertical subsurface flow constructed wetland and

89 iii) Hybrid subsurface flow constructed wetland. The most commonly used hybrid flow $\mathrm{CW}$ is 90 that in which the wastewater flows first into a horizontal flow CW (HFCW) and then to a vertical 91 flow CW (VFCW) or vice versa, whereas in a few other studies hybrid systems are differentiated 92 from other systems by introducing the baffles in the bed to make horizontal and vertical flow 
93 pattern in a single basin (Tee et al., 2012; Cui et al., 2015; Ramprasad and Philip, 2015). The

94 advantage of the hybrid system is that the nitrogen can be nitrified completely in vertical flow

95 CW and denitrified in horizontal flow CW (Sayadi et al., 2012). However, the disadvantage is

96 that it requires large areas of land and complex construction and operation. To overcome the

97 problem, a novel GROW constructed wetland (Green Roof-top Water Recycling System) was

98 developed which is suitable for use in urban areas where ground space is limited

99

100

101

102

103

104

105

106

107

108

109

110

111

112

113

114

115
The performance and working of the GROW system was originally monitored and subsequently studied at Cranfield University, UK by Avery et al., (2007), Memon et al., (2007) and Winward et al., (2008). A novel GROW system for treating 480 L/day of the hostel greywater with a hydraulic retention time of 18.6 hours. The system consisted of a sequence of trough and weirs that were placed above the wooden frame on a pitched roof. The troughs were filled with expanded clay (size $0.1 \mathrm{~m}$ ) and gravel chippings (size $0.2 \mathrm{~m}$ ) and were planted with 8 varieties of native aquatic species. They found that the GROW system was most effective in the removal of suspended solids and turbidity (mean removal rates $91.2 \%$ and $98.2 \%$, respectively). They also reported a $4.2 \log$ reduction of total coliforms in the system. With a COD and BOD removal efficiencies of $59-80 \%$ and $84-92 \%$, respectively, the treated water from the system was able to meet the stringent United States Environmental Protection Agency (USEPA) standard for water reuse $(\mathrm{BOD}<10 \mathrm{mg} / \mathrm{L})$. They also claimed that the GROW system performed better than horizontal and vertical flow constructed wetlands (Avery et al., 2007). A comparative studies on the life cycle impact assessment of GROW system with other three biological treatment systems like membrane bioreactors (MBR), membrane chemical reactors (MCR) and reed beds were done by Memon et al. (2007). They concluded that the GROW system performed best in most of 
116 the impact assessment categories and MCR appeared to be less environmentally friendly

117 (Memon et al. (2007). Similar way, another study evaluated the presence of common pathogens

118 (total coliforms, E. coli, Enterococci, Clostridia and Heterotrophs) in greywater and compared

119 the performance of GROW, VFCW, HFCW, MBR and MCR in the removal of pathogens. These

120 systems were operated continuously with a flow rate of 480 L/day with an HRT of 2.1 days. It

121 was found that MBR system provided better quality treated effluent by meeting the stringent

122 USEPA standard limits for reuse followed by VFCW, GROW, HFCW and MCR (Winward et

123 al., 2008).

124

125 In general constructed wetlands performances were affected by various factors such as climatic 126 conditions, greywater characteristics, native plant species and substrate materials. The literature

127 on GROW system were found to be mostly concentrated in the temperate maritime climate. The 128 substrate (filling) material and plant species used in the earlier studies were mostly indigenous to 129 the UK. Hence, it is necessary to evaluate the performance of the GROW system in different 130 climatic conditions, vegetation patterns and greywater characteristics to determine the suitability 131 of the system in other regions. Moreover, previous studies on GROW systems were conducted 132 mostly at one particular flow rate, at constant HRT and at single organic loading rate (OLR). 133 Information regarding the fate of surfactants and personal care products in GROW systems, is 134 also lacking. Therefore, the present study focused on the evaluation of the performance of the 135 GROW system in Indian tropical conditions and with native filling materials (sand, brick bat and 136 gravel (1:1:1)) and 8 different plant species commonly available in India (Canna indica, Canna 137 flaccida, Canna lily - hybrid, Cardamina pratensis, Plectranthus amboinicus, Crossandrain 138 fundibuliformis, Phragmiies australis, Solanum trilobatum), at different flow rates (62, 70, 82, 
139100 and $120 \mathrm{~L} /$ day), and organic loading rates (26.8, 25.9 and $25.5 \mathrm{~g} \mathrm{COD/} \mathrm{cubic.} \mathrm{meter/} \mathrm{day).}$

140 The study also evaluated the effect of seasonal variations, change of plant species and substrate

141 materials on the performance of GROW system. The fate of surfactants in GROW system was

142 also evaluated.

144 2. Materials and Methods:

$145 \quad$ 2.1 GROW constructed wetlands:

146 A novel constructed wetland system, Green Roof-Top Water Recycling System (GROW), was

147 developed by Water Works UK Ltd., London, UK and was fabricated and installed in Krishna

148 Hostel, IIT Madras, Chennai, India (GPS coordinates12 59' $1.266^{\prime \prime} \mathrm{N} ; 80^{\circ} 13^{\prime} 57.3852^{\prime \prime}$ E).

149 Chennai lies on the thermal equator and features a tropical wet and dry climate with the 150 temperature ranging from $18^{\circ} \mathrm{C}-42{ }^{\circ} \mathrm{C}$ and average annual rainfall of $1400 \mathrm{~mm}$. The pilot scale 151 experimental system for the treatment of greywater from the hostel was in operation from 152 November, 2013 to December, 2016. The GROW system consisted of four rows of troughs 153 connected laterally and placed on a mild steel scaffolding frame. Each row consisted of two 154 troughs mounted in series and butted up to each other. The scaffolding frame was placed on the

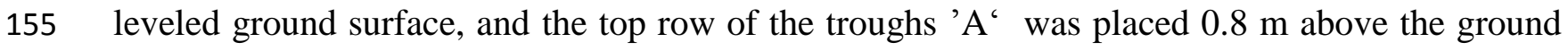
156 surface and the lowest one (trough 'D') was positioned at $0.4 \mathrm{~m}$ above the ground surface (Fig. 157 1). The troughs of the GROW system were made of high density polyethylene sheet of $6 \mathrm{~mm}$ 158 thickness $4 \mathrm{~m}$ length and $2 \mathrm{~m}$ wide. The trough had a depth of $25 \mathrm{~cm}$ with a water holding 159 capacity $125 \mathrm{~L}$ per trough. The troughs were fitted with intermediate 'baffles' and 'weirs' 160 arranged in such a way that the wastewater was forced to have contact with the whole depth of 161 media/ substrate and thereby reducing any short-circuiting. In first phase of the study, troughs 
162 were filled with a support medium which consisted of a mixture of sand, brick bats and gravel in

163 equal proportion $(1: 1: 1)$ to approximately $15 \mathrm{~cm}$ depth. The total volume of the GROW system

164 was 1.84 cubic. meter and each substrate material occupied a volume of 0.4 cubic meters.

165

166 The troughs were planted with 8 varieties of native plant species of Canna indica, Canna 167 flaccida, Canna lily - hybrid, Cardamine pratensis, Plectranthus amboinicus, Crossandrain 168 fundibuliformis, Phragmites australis, Solanum trilobatum. The planting plan employed for the 169 study is shown in Fig 2. Trough 1 was used only with substrate without any plants to act as an 170 additional settling unit; trough 2 was planted with 4 plants of Canna indica, trough 3 was 171 planted with 4 Canna flaccid, trough 4 was planted with Canna lily - hybrid (3 numbers), trough 1725 was planted with 3 plants of Cardamine pratensis and, trough 6 was planted with 3 plants of 173 Plectranthus amboinicus, trough 7 was planted with 1 plant of Canna indica and 2 plants of 174 Solanum trilobatum, trough 8 was planted with 1 plant of Phragmites australis and 1 plant of 175 Crossandrain fundibuliformis, trough 9 was planted with 4 numbers of Crossandrain 176 fundibuliformis, trough 10 was planted with 2 numbers of Canna lily - hybrid, and 3 varieties of 177 Canna flaccid, trough 11 and 12 were planted with 5 numbers of Canna indica. In Phase 1, 178 above mentioned plant species were planted on the trough having a surface area of 8 square. 179 meter with a plant density of 4 plants per square. meter. In phase 2, the substrate material filled 180 was removed and replaced with gravel of size $<5 \mathrm{~cm}$ and the plants were replaced with Canna $181 S p$ with a planting density of 4 plants per square. meter. 
184 In phase 1, the filter media used was a mixture of sand, brick bats and gravel of equal proportion 185 (1:1:1). Three different filter media were purchased commercially, sand with a particle size of $1860.5 \mathrm{~mm}$, gravel $(10 \mathrm{~mm})$ and brick bat of size $<5 \mathrm{~cm}$ were filled in the troughs for a depth of 15 $187 \mathrm{~cm}$. In phase 2, the old filter media were replaced completely with gravel of particle size $<10$ $188 \mathrm{~mm}$.

\subsection{Greywater Sources:}

191 The influent raw greywater was collected from the Krishna student hostels on IIT Madras 192 campus, Chennai, India. Wastewater from baths, showers, wash basins and washing machine 193 were collected separately and drained into a common settling tank from which $100 \mathrm{~L}$ was 194 pumped to an over head tank. The greywater from the overhead tank was allowed to flow by 195 gravity into the GROW system through a flow control valve. The water entered from one trough 196 to another (1 to 12 ) through the weirs and baffles continuously from the top trough to bottom 197 trough where it reached the outlet pipe. The greywater was supplied to the GROW system 198 continuously with a hydraulic loading rate of 53.1 - 58.9 L/ cubic. meter/ day with a hydraulic 199 retention time varied from 0.7 to 1.3 days. The operating history of GROW system is tabulated 200 in Table 1.

\section{2.4 Sampling and Analysis:}

203 The raw greywater and treated water samples were collected every week starting from 204 November, 2013 between 09:00 and 12.00 hours. In addition, samples were collected from the 205 end of each row of troughs 1,2,3 and 4 every month. The samples were carried to the laboratory 206 in air tight plastic bottles and were stored in refrigerator at $4^{\circ} \mathrm{C}$. The water samples were further 
examined for the physico-chemical and biological parameters as per standard methods for the examination of water and wastewater (APHA, 2012). $\mathrm{pH}$ of the sample was analyzed using

209 Eutech cyberscan PCD 650 multi parameter kit (Thermo scientific, Singapore). Chemical oxygen 210 demand (COD) was measured using a closed reflux chromate titrimetric method, Biochemical 211 oxygen demand (BOD) was measured using the 5 day incubation method, Total organic carbon 212 (TOC) and total nitrogen (TN) were measured using total organic carbon analyzer V600 series 213 (Shimandzu, Japan).Nitrate nitrogen $\left(\mathrm{NO}_{3}-\mathrm{N}\right)$ and total phosphate (TP) was analyzed using UV 214 spectrometer (UV-VIS 8000, Shimandzu, Japan) (APHA, 2012). Fecal coliform (FC) was 215 measured by chromocult nutrient media plates supplied by Sartorius, Germany. The sodium do216 decyl sulphate (SDS) was measured calorimetrically at $467 \mathrm{~nm}$ using a UV 1800 217 spectrophotometer (Shimadzu, Japan). Propylene glycol and Trimethyl amine were measured 218 using gas chromatography fitted with flame ionization detector (PerkinElmer Clarus 500).

\subsection{Statistical Analysis}

221 The performance of the GROW constructed wetland system was statistically evaluated by 222 comparing the means of effluent concentrations of various parameters under different operating 223 conditions, using paired sample ' $t$ ' test. The paired ' $t$ ' test are commonly applied for comparing 224 the means of data's from two related samples or variables. The statistical analysis was performed 225 using IBM SPSS statistics 20 software at 95\% confidence level $(\mathrm{p}<0.05)$.

\section{3. Results and Discussion}

\section{$228 \quad 3.1$ Influent raw greywater quality}


229 The raw wastewater characteristics analyzed over a period of time is shown in Table 2. In 230 general the pollutant concentrations such as organics, solids and indicator organisms in 231 greywater are comparatively less than that in domestic wastewater. The greywater also has lesser 232 macronutrients ( $\mathrm{N}$ and $\mathrm{P}$ ) than the domestic wastewater. The organics concentration and fecal 233 coliforms of greywater used in this study were lower than the reported values. The mean value of 234 COD was 216-320 mg/L and BOD was 68-120 mg/L. The obtained values of COD and BOD 235 were lesser than earlier reported values by Gilboa and Friedler, 2008. The reason for lesser 236 concentration of these parameters is apparently due to the very high per capita water 237 consumption. The COD: BOD ratio was in the range of 2.7-3.0, which indicates that greywater 238 contains higher amount of recalcitrant organics than sewage (Metcalf et al, 2010). The reason 239 for higher COD: BOD ratio may be due to higher usage of surfactants and personal care products 240 during laundry services. As no urination bowls were connected with the separated greywater, the 241 concentrations of nitrogenous and phosphorus compounds in greywater were also lesser than the 242 reported values. The phosphorus present in the greywater mostly originated from the detergents 243 used in washing powders. The values of emerging contaminants i.e., surfactants namely sodium 244 do-decyl sulphate (SDS), propylene glycol (PG) and trimethyl amine (TMA) were present in the 245 concentration ranges of 14.9-35.9 mg/L, 11.6-46.6 mg/L and 8.7-15.5 mg/L, respectively. The 246 obtained values were similar to earlier reported values for SDS by Gross et al., 2007. There were 247 no supporting data available regarding the concentrations of PG and TMA in the raw greywater.

\subsection{Performance of GROW System under different operational conditions}

250 The performance of GROW system was evaluated in two different phases, phase 1 was further 251 subdivided into four different sub-phases viz. a viz., start-up phase (Phase1.1), seasonal variation 
252 (Phase 1.2), flow rate variations (Phase1.3) and organic load variations (Phase1.4). The first 4 253 weeks of Phase 1.1.covered the start-up stages of the GROW system. During this phase, the 254 system was fed with greywater at the flow rate of 70 L/day. During this period, the plants and 255 microbes were allowed to acclimatize to the newer environment. In Phase1.2, the performance of 256 the GROW system at various seasons and temperature, i.e., summer, monsoon, pre-monsoon and 257 post monsoon, were evaluated for the designed flow rate of $70 \mathrm{~L} /$ day. In phase 1.3 , different 258 hydraulic loading rates were employed, i.e., 62 L/day, 82 L/day, 100 L/day and 120 L/day. 259 Finally in Phase1.4, the performance of the system was evaluated for various organic loading 260 rates (25.5 g COD/ cubic. meter/ day, $25.9 \mathrm{~g} \mathrm{COD/} \mathrm{cubic.} \mathrm{meter/} \mathrm{day} \mathrm{and} 26.8 \mathrm{~g}$ COD/ cubic. 261 meter/ day) by adding sucrose as an external carbon source at a flow rate of 100 L/day. In Phase

262 2, the GROW system was operated at constant flow rate of 100 L/day to evaluate the effect of 263 different substrate materials and plant species on the performance of GROW system. The short 264 term equilibrium was attained within 2 months from the date of plantation in the GROW system 265 and performing well after 3 years of continuous operation. If the GROW system is properly 266 maintained, the system can work for another 2-3 years.

\subsubsection{Organics}

269 During the study period, the influent BOD and COD varied from 68-120 mg/L and 216-320 $270 \mathrm{mg} / \mathrm{L}$, respectively as shown in Table 2 . However, the variation of influent quality did not affect 271 the outlet biochemical oxygen demand (BOD) and chemical oxygen demand (COD) 272 concentrations during the monitoring period. It was consistently below $10 \mathrm{mg} / \mathrm{L}$ for BOD and 20 $273 \mathrm{mg} / \mathrm{L}$ for COD, which is below the USEPA standard limits for secondary reuse. It was also found 274 that the GROW system showed a better removal efficiency during the summer season compared 
275 to other seasons as shown in Fig 3(a)-(b). As stated by Vymazal, 2002; Akratos and Tsihrintzis, 2007 that the organic pollutants are removed mostly by microbial degradation and also by

277 adsorption to a certain extent. Hence, at an elevated temperature, the activities of aerobic and 278 anaerobic microbes are enhanced, resulting in higher organic pollutant degradation during 279 summer season. During phase 1.3, it was found that the BOD and COD concentration in the 280 effluent were comparable at the flow rates of 62, 82 and $100 \mathrm{~L} /$ day and were increased as the 281 flow rate increased to $120 \mathrm{~L} /$ day. This indicates that $100 \mathrm{~L} /$ day can be considered as the optimal 282 flow rate for the maximum pollutant removal. As the flow rate increased, the retention time 283 (HRT) decreased, resulting in lesser removal of organic pollutant. Similar results were reported 284 by Akratos and Tsihrintzix, 2007. In phase 1.4, the effluent BOD and COD concentrations were 285 changed slightly. As the OLR increased from 25.5 to $26.8 \mathrm{~g}$ COD/ cubic. meter/ day, the effluent 286 COD and BOD concentrations were increased. It was observed that at $26.8 \mathrm{~g} \mathrm{COD} /$ cubic. meter/ 287 day, the COD values were $16-24 \mathrm{mg} / \mathrm{L}$, while it was <16 mg/L during the other two OLRs. 288 These results were in accordance with the results reported by Lin et al., 2002 and Saeed and Sun, 289 2012. This indicates that $26.8 \mathrm{~g}$ COD/cubic. meter/day OLR exceeded the degradation capacity 290 of the wetland system (Dalahmeh et al., 2014). The variance of means of the effluent quality at 291 various monitoring periods were found to be statistically significant $(\mathrm{p}<0.05)$ [Supplementary 292 Table S1]. In phase 2, the COD and BOD removal efficiency was found to be $88 \%$ and $84 \%$, 293 respectively [Supplementary Fig. S1]. The reason is that the organic pollutants are mostly 294 removed by microbial degradation and by adsorption (Vymazal, 2002).

\subsubsection{Suspended solids}


297 The inlet and outlet suspended solids concentrations and percentage removal during the 298 monitoring period are shown in Fig. 4. The suspended solids in the constructed wetlands are 299 removed from the wastewater by physical processes such as filtration and sedimentation 300 (Haghshenas-Adarmanabadi et al., 2016). According to Masi and Martinuzzi (2007), the solids 301 removals by the constructed wetlands are in the range of $72-84 \%$ in the Mediterranean countries, 302 and $65-91 \%$ in the tropical regions of developing countries (Singh et al., 2014). In the present 303 study about $85-90 \%$ ( $<20 \mathrm{mg} / \mathrm{L})$ removal of solids particles from inlet to outlet tank was 304 achieved. The reason for higher removal efficiency may be due to the baffled CW configuration 305 that prolonged the water flow path and enhanced the filtration process which favored the removal 306 of suspended solids.

It was also observed from Fig. 4 that during phase 1.1, the removal of suspended solids was less $(<80 \%)$. The microbes and plants started growing at this stage and they were not completely matured. This may be the reason for the low performance. As the time progressed, in phase 1.2, the removal of solids improved and remained almost at a constant level (88-95\%). During phase 1.3, (i.e., change of flow rate), it was observed that as the flow rate increased, the removal of solids concentration decreased due to lesser hydraulic retention time. Similar results were 314 reported by other researchers also (Akaratos and Tsihrintzis, 2007). As the organic load were increases from 25.5 to $26.8 \mathrm{~g} \mathrm{COD/cubic.} \mathrm{meter/} \mathrm{day,} \mathrm{the} \mathrm{solids} \mathrm{concentration} \mathrm{in} \mathrm{treated} \mathrm{water}$ 316 also increased. The above obtained results were in good agreement with Dominguez et al., 2012 317 that the increased organic loading rate resulted in increased biomass growth which in turn 318 increased the suspended solids concentration in the effluent. However, the overall removal of 319 solids was comparatively lesser compared to other constructed wetlands like horizontal, vertical 320 and hybrid flow systems (Ramprasad and Philip, 2016). The statistical analysis (paired't' test) 
321 were conducted to evaluate the performance of GROW system for the removal of solids during

322 various monitoring periods (start-up, seasonal, hydraulic loading rate and organic loading rate)

323 and paired ' $t$ ' test showed that the treated effluent quality during all the monitoring periods are

324 statistically significant at $95 \%$ confidence interval $(p<0.05 ; p=0.039)$ [Supplementary Table

325 S1]. The removal of suspended solids was highly affected by lowering the HRT and increasing 326 the OLR.

\subsubsection{Nutrients}

329 Nutrients (nitrogen and phosphorous) presence in wastewater is one of the major factors that 330 causes eutrophication, deplete the dissolved oxygen level and can be toxic to the ecosystem. 331 Generally, the removal of nutrients is by ammonification, nitrification, denitrification, plant 332 uptake, volatilization and biomass assimilation (Vymazal, 2002; Akratos and Tsihrintzis, 2007). 333 In the present study, the concentrations of nitrates, ammonia and phosphates present in the 334 influent were low as compared to earlier reports (Gilboa and Friedler, 2008; Antonopoulou et al., 335 2013). The nitrogen compounds removal was around 88 to $99 \%$ during summer season and was 336 found to be lesser during other seasons (Fig. 5-). Microbial reactions such as organic nitrogen 337 decomposition, nitrification and de-nitrification are favored at higher temperature resulting in 338 greater removal efficiency. Similar to nitrogen compounds, phosphate removal was also favored 339 at high temperatures. During the summer season, the removal of total phosphate was maximum 340 at $92 \%$, which was less during other seasons (Fig. 6). It was reported in earlier studies that the main mechanism involved in phosphate removal were sorption and plant uptake (Vymazal,

342 2002). Sorption of phosphate is an endothermic reaction (Jin et al., 2005), which means that low 343 temperatures decrease the sorption capacity of the bed (Rustige et al., 2003). The results obtained 
344 by GROW systems were compared with the other three wetlands (horizontal vertical and hybrid)

345 studied by Ramprasad and Philip, 2016. The hybrid wetland performed better than GROW and

346 other two systems. Many reports suggested that the nutrients removal in constructed wetlands

347 was predominantly due to de-nitrification activity (Vymazal, 2002). During phase 1.3, enhanced

348 activity of de-nitrifiers was observed due to high HRT which resulted in higher removal rate. In

349 phase 1.4, as the OLR increased from 25.5 to $26.8 \mathrm{~g} \mathrm{COD/} \mathrm{cubic.} \mathrm{meter/} \mathrm{day,} \mathrm{the} \mathrm{removal} \mathrm{rates}$

350 of nutrients increased (Fig. 5-6). The probable reason might be that, increased organic load

351 triggered an increased growth of anoxic microbes near the root nodules, providing a favorable

352 condition for de-nitrification (Dalahmeh et al., 2014). The statistical analysis confirms that the

353 effect of different operating conditions on the nutrients content was recognized as highly

354 significant $(\mathrm{T}=4.367 ; p=0.005)$.

355

356 In phase 2, the removal of nutrients and phosphate were in the range of $82-88 \%$ and $65-74 \%$,

357 respectively [Supplementary Fig S1]. The GROW system was capable of removing the nutrients

358 from the greywater below the reusable standard level. It was observed that the nitrate - nitrogen

359 in the treated wastewater were in the range of $1.2-3.5 \mathrm{mg} / \mathrm{L}$ and $0.8-1.4 \mathrm{mg} / \mathrm{L}$ for total 360 phosphates. (Fig. 5 - 6)

\subsubsection{Fecal Coliforms}

363 The fecal coliform concentration in the inlet was relatively low (50-120 CFU/100 mL) compared 364 to the earlier reported values (Antonopoulou et al., 2013). The major reason for the lesser 365 coliform contamination may be due to the age group of inhabitants and avoidance of kitchen 366 wastewater. Most of the inmates were in the age group of 19-25 years. The fecal coliform 
removal in constructed wetland is attributed to physical process such as sedimentation, filtration and natural die-off. The removal rates of the fecal coliform were in the range of $70-85 \%$ during the start-up stage, and gradually increased and reached around 98\% during phase 1.2. It is clear from Fig 7 that during the summer seasons the FC removal was more than the other seasons. It is

371 also evident that with increase in hydraulic retention time, during phase 1.3 , the removal rates 372 also increased from 94\% to 98\% (Fig 7). Akaratos and Tsihrintzis, 2007 have previously 373 reported that as the HRT increased the coliform have higher contact time in the system to get 374 removed or degraded resulting in higher removal efficiency. As the OLR increased, the effluent 375 coliform concentration also increased from $4 \mathrm{CFU} / 100 \mathrm{~mL}$ to $12 \mathrm{CFU} / 100 \mathrm{~mL}$, due to increased 376 biomass growth by utilizing the readily available carbon source. . Similar results were reported 377 by other researchers also (Dalahmeh et al., 2014). Statistically significant difference $(\mathrm{p}<0.05$; $378 \mathrm{~T}=5.860$ ) in the average fecal coliform content occurred in different operational phases. During 379 Phase 2, the fecal coliform removal was in the range of $88-90 \%$. The coliform removal 380 efficiency of phase 2 was comparatively lower than one obtained during phase 1 . The reason for 381 lesser removal is due to the high pore size available in gravel medium compared to sand gravel 382 mix. In-spite of higher removal efficiency, the coliform counts did not comply with the USEPA 383 standard limits for reuse. Therefore the treated water should be provided with little dose of 384 disinfectant before reused.

\subsubsection{Emerging contaminants}

\subsubsection{Sodium do-decyl sulphate}

388 Sodium do-decyl sulphate (SDS) is the most commonly used surfactant, and the removal 389 efficiency of this pollutant in GROW system varied between 85-96\% (Fig. 8) SDS is considered 
to be highly hydrophobic in nature having a $\log \mathrm{K}_{\mathrm{ow}}$ of 3.6 (Hansch et al., 1996). Generally, the compounds that are hydrophobic (with high $\mathrm{K}_{\mathrm{ow}}$ ) values are removed from the system by adsorption, hydrolysis and microbial degradation/ biosorption (Lv et al., 2016; Ramprasad and

393 Philip, 2016). The SDS in the treated water was in the range of $2.8-4.2 \mathrm{mg} / \mathrm{L}(60-80 \%)$ during 394 the start-up phase, and was improved in the following phases to 82-96\%. It was also found that 395 the removal of SDS was affected by seasons. The seasonal variability was mainly attributed to 396 two main physical conditions, namely solar radiation and water temperature. Low temperatures 397 decreased the bio-degradation rates and low solar irradiation decreased the phyto degradation 398 rates (Simonich et al., 2002). In phase 1.3, the removal efficiency of SDS increased from $88 \%$ to $39996 \%$ with decrease in flow rate and increased hydraulic retention enhanced the biodegradation of 400 adsorption of SDS. This is in good agreement with the results reported by Langford et al., 2005. 401 In phase 1.4, as the OLR increased from $25.5 \mathrm{~g} \mathrm{COD/} \mathrm{cubic.} \mathrm{meter/} \mathrm{day} \mathrm{to} 26.8 \mathrm{~g} \mathrm{COD/} \mathrm{cubic.}$ 402 meter/ day, the rate of SDS removal decreased from $92 \%$ to $85 \%$. The presence of readily 403 available carbon source (sucrose) reduced the biodegradability of SDS as reported by Nyberg et 404 al., 1992. The statistical analysis confirms that, although the difference in the effluent SDS 405 concentrations is statistically significant $(\mathrm{p}<0.05)$, it is relatively small. The SDS removal 406 efficiency after the change of plant species and filling media was reduced to $85-88 \%$, due to the 407 availability of less adsorption space as the media sizes were larger.

\subsubsection{Propylene Glycol and Tri Methyl amine}

410 The propylene glycol (PG) and tri-methyl amine (TMA) are commonly used in personal care

411 products likes soap and shampoos. PG and TMA are highly water soluble, have low log $\mathrm{K}_{\mathrm{ow}}$ 412 value and are also easily biodegradable. It was reported by Avila et al., 2014, that the compounds 
413 that are highly water soluble is predominantly taken up by plants / phyto-degraded and

414 biodegraded. In phase 1.1, the PG and TMA removal efficiency was in the range of 40-60\%

415 (Fig. 9 and 10) due to the low density of plants and microbes in the system. During phase 1.2,

416 the, the removal efficiency was more during summer than in winter or monsoon. In phase 1.3, as

417 the flow rate increased, the removal efficiency decreased (96\% to $80 \%$ ), due to less retention

418 time. Also, when the OLR increased (25.5 to $26.8 \mathrm{~g}$ COD/ cubic. meter/ day) the removal

419 efficiency decreased from $94 \%$ to $86 \%$, as the system exceeded the biodegradation capacity. Due

420 to addition of external carbon source, the degradation rates of organic pollutants were hindered.

421 Sucrose is a readily biodegradable compound than PG and TMA. Therefore, microbial consortia

422 would have utilized more sucrose as a carbon source than the target pollutant. As a result, lesser

423 biodegradation was observed for target pollutants with increase in OLR. Similar trend was

424 reported by other researchers also (Nyberg et al., 1992). During phase 2, the removal efficiency

425 did not change much from phase 1, as the mechanism for PG and TMA removal was mostly 426 plant uptake and biodegradation.

\section{4. Conclusion}

429 This study confirmed that shallow horizontal subsurface flow GROW system with 8 varieties of 430 native plant species can effectively improve quality of greywater in tropical countries. The 431 performance of the GROW system was monitored over a significant period of time at various 432 operating conditions. The removal efficiency obtained for various parameters were; biochemical 433 oxygen demand (BOD) 90.8\%, chemical oxygen demand (COD) 92.5\%, total suspended solids 434 (TSS) 91.6\%, nitrate-nitrogen $\left(\mathrm{NO}_{3}-\mathrm{N}\right)$ 83.6\%, total phosphate (TP) 87.9\%, total nitrogen (TN) $43591.7 \%$, fecal coliform (FC) 91.4\%, sodium do-decyl sulphate (SDS) 85.7\%, propylene glycol 
436 (PG) 93.4\% and trimethyl amine (TMA) 88.9\%. It was found that the removal rate was high

437 during summer season compared to other seasons. Also the removal efficiency was more at

438 higher HRT. The promising results from this study may increase the applicability of GROW 439 systems as a robust, cost-effective and reliable green roof systems in India and other tropical 440 countries.

441

442 Acknowledgement:

443 The authors wish to acknowledge Department of Science of Technology (DST), India and the 444 European Union for providing the financial support for the project SARASWATI.

445

446 References:

447 1. Akratos, C. S., \&Tsihrintzis, V. A. (2007). Effect of temperature, HRT, vegetation and 448 449 porous media on removal efficiency of pilot-scale horizontal subsurface flow constructed wetlands. Ecological engineering, 29(2), 173-191.

2. Antonopoulou, G., Kirkou, A., \&Stasinakis, A. S. (2013). Quantitative and qualitative greywater characterization in Greek households and investigation of their treatment using physicochemical methods. Science of the Total Environment, 454, 426-432.

3. APHA, American Public Health Association, \& American Water Works Association. (2012). Standard methods for the examination of water and wastewater: selected analytical methods approved and cited by the United States Environmental Protection Agency. American Public Health Association. 
4. Avery, L. M., Frazer-Williams, R. A., Winward, G., Shirley-Smith, C., Liu, S., Memon, F. A., \& Jefferson, B. (2007). Constructed wetlands for grey water treatment. Ecohydrology\& Hydrobiology, 7(3), 191-200.

5. Ávila, C., Matamoros, V., Reyes-Contreras, C., Pina, B., Casado, M., Mita, L., ...\&Bayona, J. M. (2014). Attenuation of emerging organic contaminants in a hybrid constructed wetland system under different hydraulic loading rates and their associated toxicological effects in wastewater. Science of the Total Environment, 470, 1272-1280.

6. Cui, L., Ouyang, Y., Yang, W., Huang, Z., Xu, Q., \& Yu, G. (2015). Removal of nutrients from septic tank effluent with baffle subsurface-flow constructed wetlands. Journal of environmental management, 153, 33-39.

7. Dalahmeh, S. S., Pell, M., Hylander, L. D., Lalander, C., Vinnerås, B., \&Jönsson, H. (2014). Effects of changing hydraulic and organic loading rates on pollutant reduction in bark, charcoal and sand filters treating greywater.Journal of environmental management, 132, 338-345.

8. do Couto, E. D. A., Calijuri, M. L., Assemany, P. P., da Fonseca Santiago, A., \& Lopes, L. S. (2015). Greywater treatment in airports using anaerobic filter followed by UV disinfection: an efficient and low cost alternative. Journal of Cleaner Production, 106, 372-379.

9. Domínguez, L., Cases, V., Birek, C., Rodríguez, M., \& Prats, D. (2012). Influence of organic loading rate on the performance of ultrafiltration and microfiltration membrane bioreactors at high sludge retention time. Chemical Engineering Journal, 181, 132-143.

10. Eriksson, E., Auffarth, K., Henze, M., \&Ledin, A. (2002). Characteristics of grey wastewater. Urban water, 4(1), 85-104. 
11. Frazer-Williams, R., Avery, L., Winward, G., Jeffrey, P., Shirley-Smith, C., Liu, S., ...\& Jefferson, B. (2008). Constructed wetlands for urban grey water recycling. International Journal of Environment and Pollution, 33(1), 93-109.

12. Gilboa, Y., \&Friedler, E. (2008). UV disinfection of RBC-treated light greywater effluent: kinetics, survival and regrowth of selected microorganisms. Water research, 42(4), 1043-1050.

13. Gross, A., Shmueli, O., Ronen, Z., \&Raveh, E. (2007). Recycled vertical flow constructed wetland (RVFCW) - a novel method of recycling greywater for irrigation in small communities and households. Chemosphere, 66(5), 916-923.

14. Haghshenas-Adarmanabadi, A., Heidarpour, M., \&Tarkesh-Esfahani, S. (2016). Evaluation of Horizontal-Vertical Subsurface Hybrid Constructed Wetlands for Tertiary Treatment of Conventional Treatment Facilities Effluents in Developing Countries. Water, Air, \& Soil Pollution, 227(1), 1-18.

15. Hansch, C., Leo, A., D. Hoekman Exploring QSAR - Hydrophobic, Electronic, and Steric Constants. Washington, DC: American Chemical Society, p. (1996) 107

16. Jefferson, B., Laine, A., Parsons, S., Stephenson, T., \& Judd, S. (2000). Technologies for domestic wastewater recycling. Urban water, 1(4), 285-292.

17. Jin, X., Wang, S., Pang, Y., Zhao, H., \& Zhou, X. (2005). The adsorption of phosphate on different trophic lake sediments. Colloids and Surfaces A: Physicochemical and Engineering Aspects, 254(1), 241-248.

18. Langford, K. H., Scrimshaw, M. D., Birkett, J. W., \& Lester, J. N. (2005). Degradation of nonylphenolic surfactants in activated sludge batch tests. Water research, 39(5), 870-876. 
19. Lin, Y. F., Jing, S. R., Wang, T. W., \& Lee, D. Y. (2002). Effects of macrophytes and

503

504

505

506

507

508

509

510

511

512

513

514

515

516

517

518

519

520

521

522

523 external carbon sources on nitrate removal from groundwater in constructed wetlands. Environmental pollution, 119(3), 413-420.

20. Lv, X., Xiao, S., Zhang, G., Jiang, P., \& Tang, F. (2016). Occurrence and removal of phenolic endocrine disrupting chemicals in the water treatment processes. Scientific reports, 6 .

21. Masi, F., \&Martinuzzi, N. (2007). Constructed wetlands for the Mediterranean countries: hybrid systems for water reuse and sustainable sanitation. Desalination, 215(1), 44-55.

22. Masi, F., Bresciani, R., Rizzo, A., Edathoot, A., Patwardhan, N., Panse, D., \& Langergraber, G. (2016). Green walls for greywater treatment and recycling in dense urban areas: a case-study in Pune. Journal of Water Sanitation and Hygiene for Development, 6(2), 342-347.

23. Masi, F., El Hamouri, B., Shafi, H. A., Baban, A., Ghrabi, A., \&Regelsberger, M. (2010). Treatment of segregated black/grey domestic wastewater using constructed wetlands in the Mediterranean basin: the zer0-m experience. Water Science and Technology, 61(1), 97-105.

24. Memon, F. A., Zheng, Z., Butler, D., Shirley-Smith, C., Lui, S., Makropoulos, C., \& Avery, L. (2007). Life cycle impact assessment of greywater recycling technologies for new developments. Environmental monitoring and assessment, 129(1-3), 27.

25. Merz, C., Scheumann, R., El Hamouri, B., \&Kraume, M. (2007). Membrane bioreactor technology for the treatment of greywater from a sports and leisure club. Desalination, 215(1), 37-43. 
26. Metcalf, L., Eddy, H. P., \&Tchobanoglous, G. (2010). Waste Water Engineering: Treatment, Disposal, and Reuse. McGraw-Hill.

27. Nyberg, U., Aspegren, H., Andersson, B., Jansen, J. L. C., \&Villadsen, I. S. (1992). Fullscale application of nitrogen removal with methanol as carbon source. Water Science and Technology, 26(5-6), 1077-1086.

28. Rakovitsky, N., Brook, I., Van Rijn, J., Ryskin, M., Mkhweli, Z., Etkin, H., \& Nir, S. (2016). Purification of greywater by a moving bed reactor followed by a filter including a granulated micelle-clay composite. Applied Clay Science, 132, 267-272.

29. Ramprasad, C., \& Philip, L. (2015). Occurrence, fate and removal of emerging contaminates in a hybrid constructed wetland treating greywater. History, 41(188), 59-66.

30. Ramprasad, C., \& Philip, L. (2016). Surfactants and personal care products removal in pilot scale horizontal and vertical flow constructed wetlands while treating greywater. Chemical Engineering Journal, 284, 458-468.

31. Rustige, H., Tomac, I., \& Höner, G. (2003). Investigations on phosphorus retention in subsurface flow constructed wetlands. Water science and technology, 48(5), 67-74.

32. Saeed, T., \& Sun, G. (2012). A review on nitrogen and organics removal mechanisms in subsurface flow constructed wetlands: dependency on environmental parameters, operating conditions and supporting media. Journal of environmental management, 112, $429-448$.

33. Sayadi, M. H., Kargar, R., Doosti, M. R., \&Salehi, H. (2012). Hybrid constructed wetlands for wastewater treatment: A worldwide review.Proceedings of the international academy of ecology and environmental sciences, 2(4), 204. 
34. Simonich, S. L., Federle, T. W., Eckhoff, W. S., Rottiers, A., Webb, S., Sabaliunas, D., \& De Wolf, W. (2002). Removal of fragrance materials during US and European wastewater treatment. Environmental science \& technology, 36(13), 2839-2847.

35. Singh, R. P., Fu, D., Fu, D., \& Juan, H. (2014). Pollutant removal efficiency of vertical sub-surface upward flow constructed wetlands for highway runoff treatment. Arabian Journal for Science and Engineering, 39(5), 3571-3578.

36. Tee, H. C., Lim, P. E., Seng, C. E., \& Nawi, M. A. M. (2012). Newly developed baffled subsurface-flow constructed wetland for the enhancement of nitrogen removal. Bioresource technology, 104, 235-242.

37. Thanh, B. X., Hai Van, P. T., Tin, N. T., Hien, V. T. D., Dan, N. P., \& Koottatep, T. (2014). Performance of wetland roof with Melampodium paludosum treating septic tank effluent. Desalination and Water Treatment, 52(4-6), 1070-1076.

38. Vymazal, J. (2002). The use of sub-surface constructed wetlands for wastewater treatment in the Czech Republic: 10 years experience. Ecological Engineering, 18(5), 633-646.

39. Winward, G. P., Avery, L. M., Frazer-Williams, R., Pidou, M., Jeffrey, P., Stephenson, T., \& Jefferson, B. (2008). A study of the microbial quality of grey water and an evaluation of treatment technologies for reuse. Ecological engineering, 32(2), 187-197. 


\title{
Removal of chemical and microbial contaminants from greywater using a
} novel constructed wetland GROW

\author{
Ramprasad $^{\mathrm{a}}$, Chris Shirley Smith ${ }^{\mathrm{b}}$, Fayyaz A. Memon ${ }^{\mathrm{c}}$ and Ligy Philip*a \\ *Corresponding author; E-mail: ligy@iitm.ac.in \\ ${ }^{a}$ Department of Civil Engineering, Environment and Water Resource Engineering Division, \\ Indian Institute of Technology Madras, Chennai, Tamil Nadu, India. \\ ${ }^{\mathrm{b}}$ Director, Alternative Water Solutions, London, United Kingdom. \\ ${ }^{\mathrm{c}}$ School of Engineering, Computing and Mathematics, Harrison Building, University of Exeter, \\ Exeter, United Kingdom.
}

\section{$\underline{\text { List of Figures }}$}

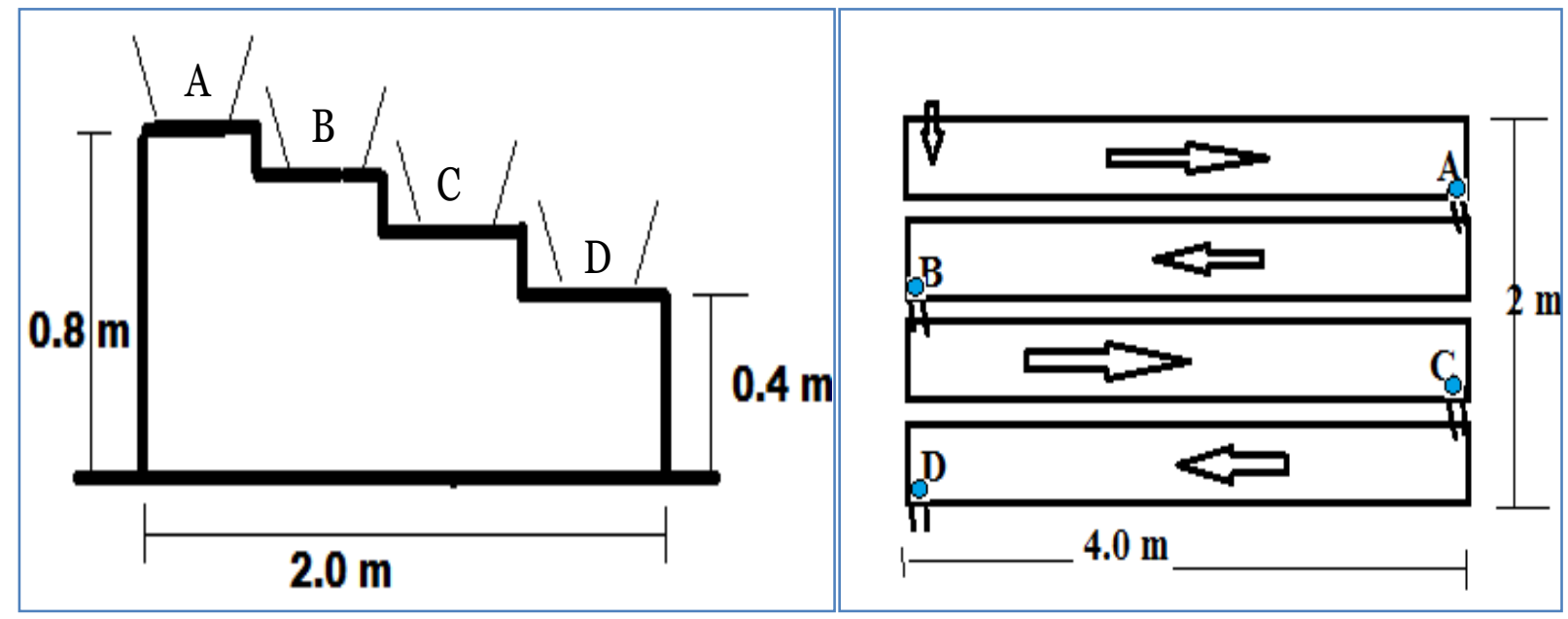

Fig. 1 Schematics of GROW system 


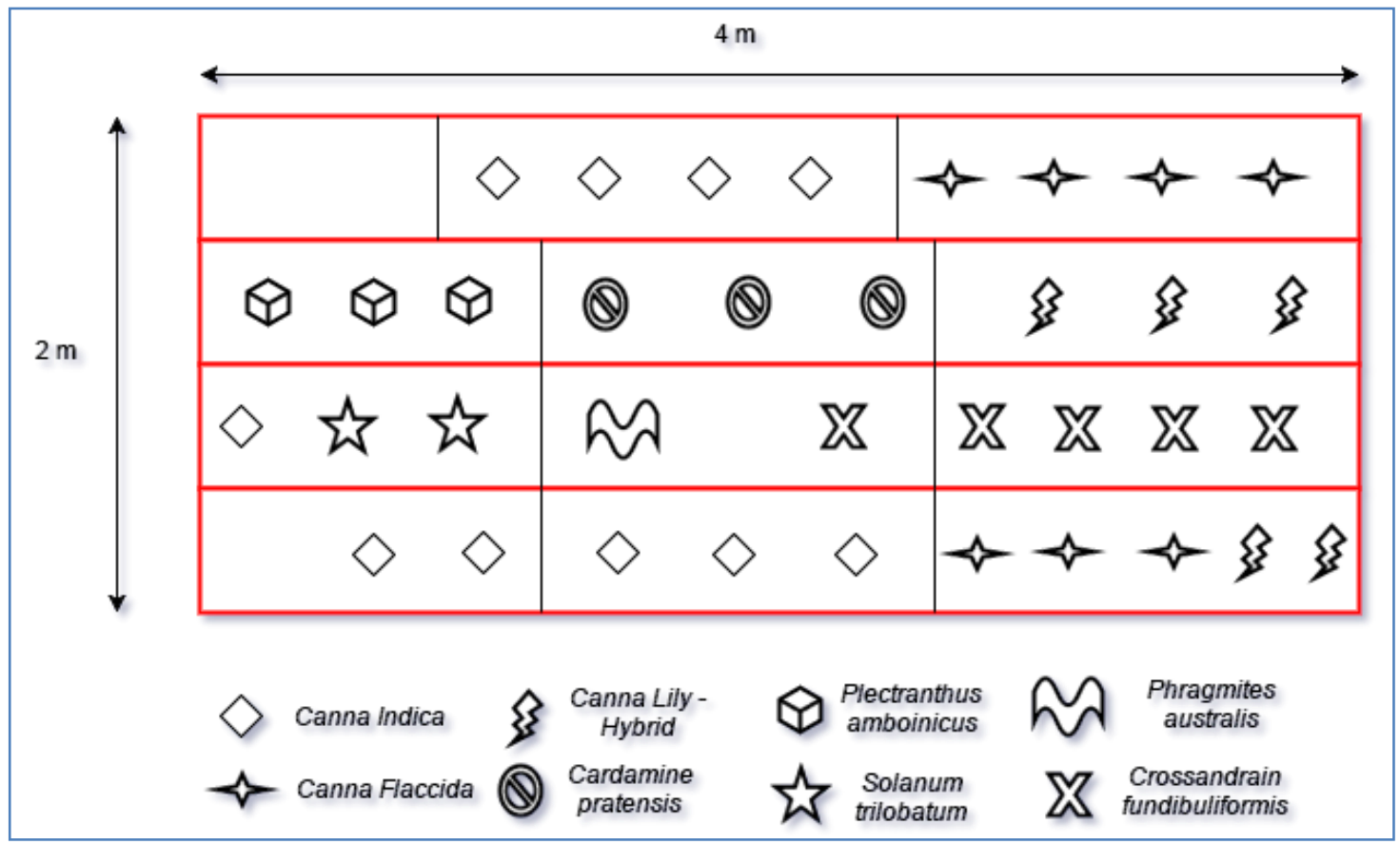

Fig. 2 Planting Plan of Each trough in GROW system

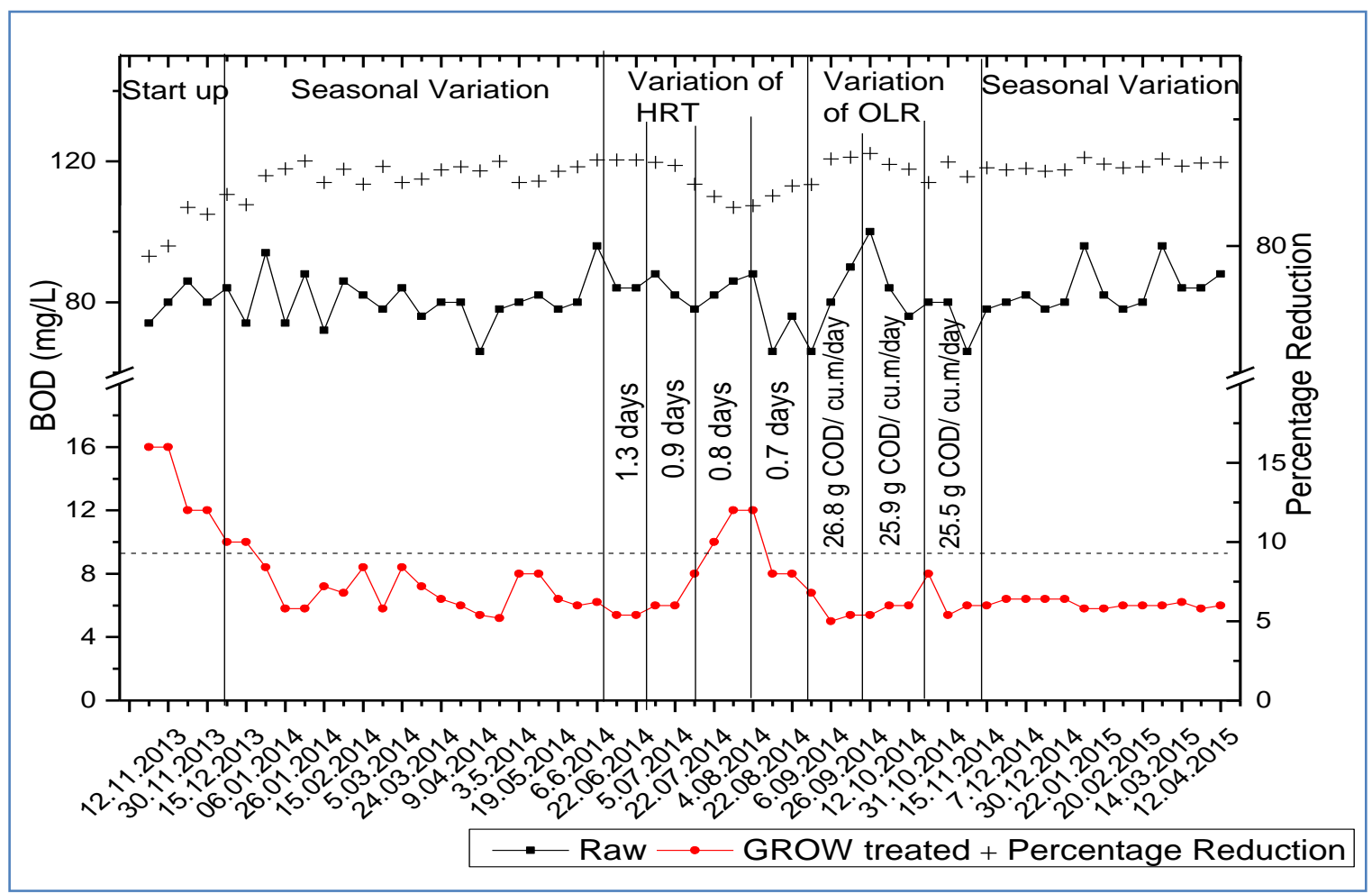

Fig. 3(a) Performance of GROW systems with respect to BOD removal during various operational conditions 


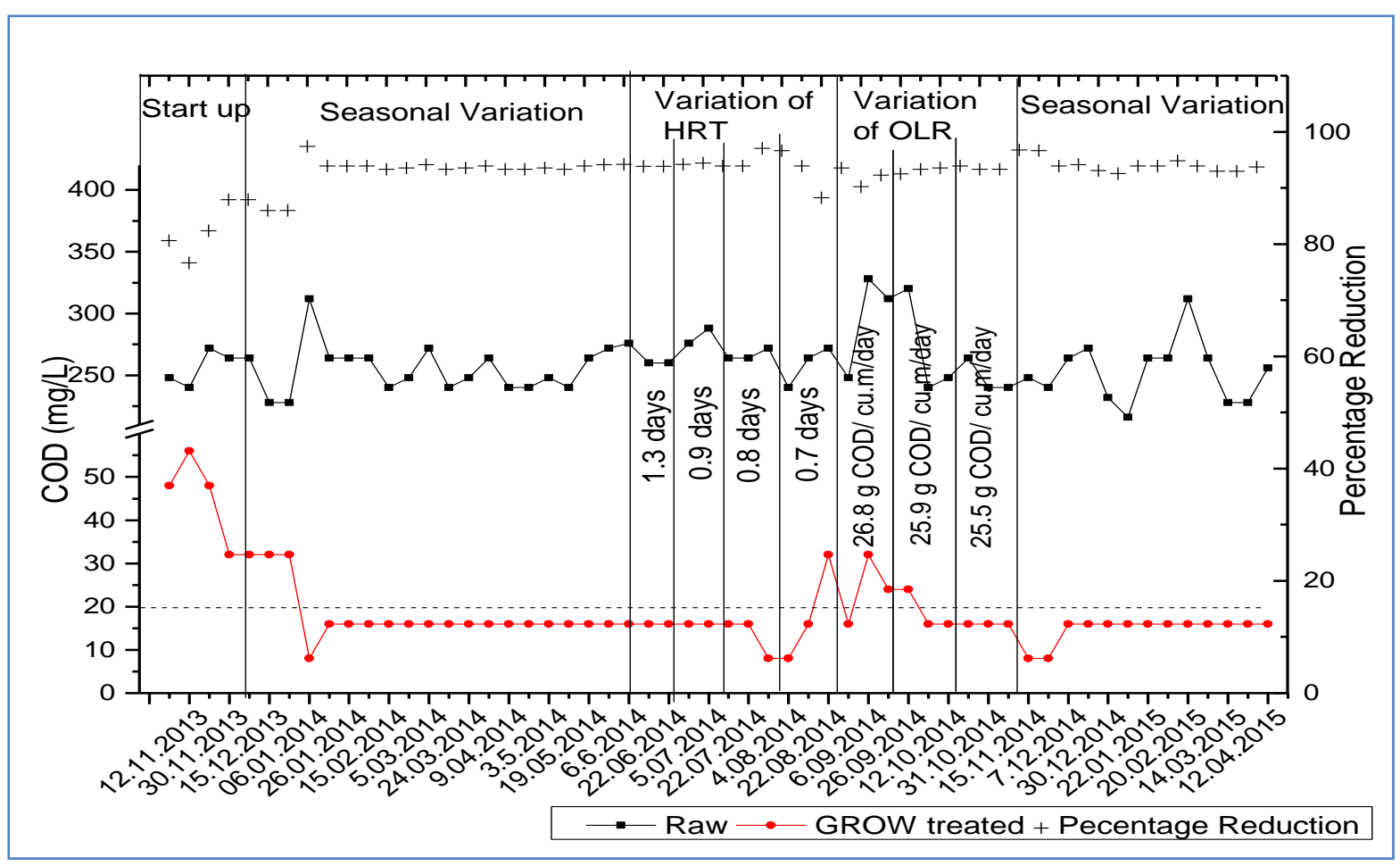

Fig. 3(b) Performance of GROW systems with respect to COD removal during various

\section{operational conditions}

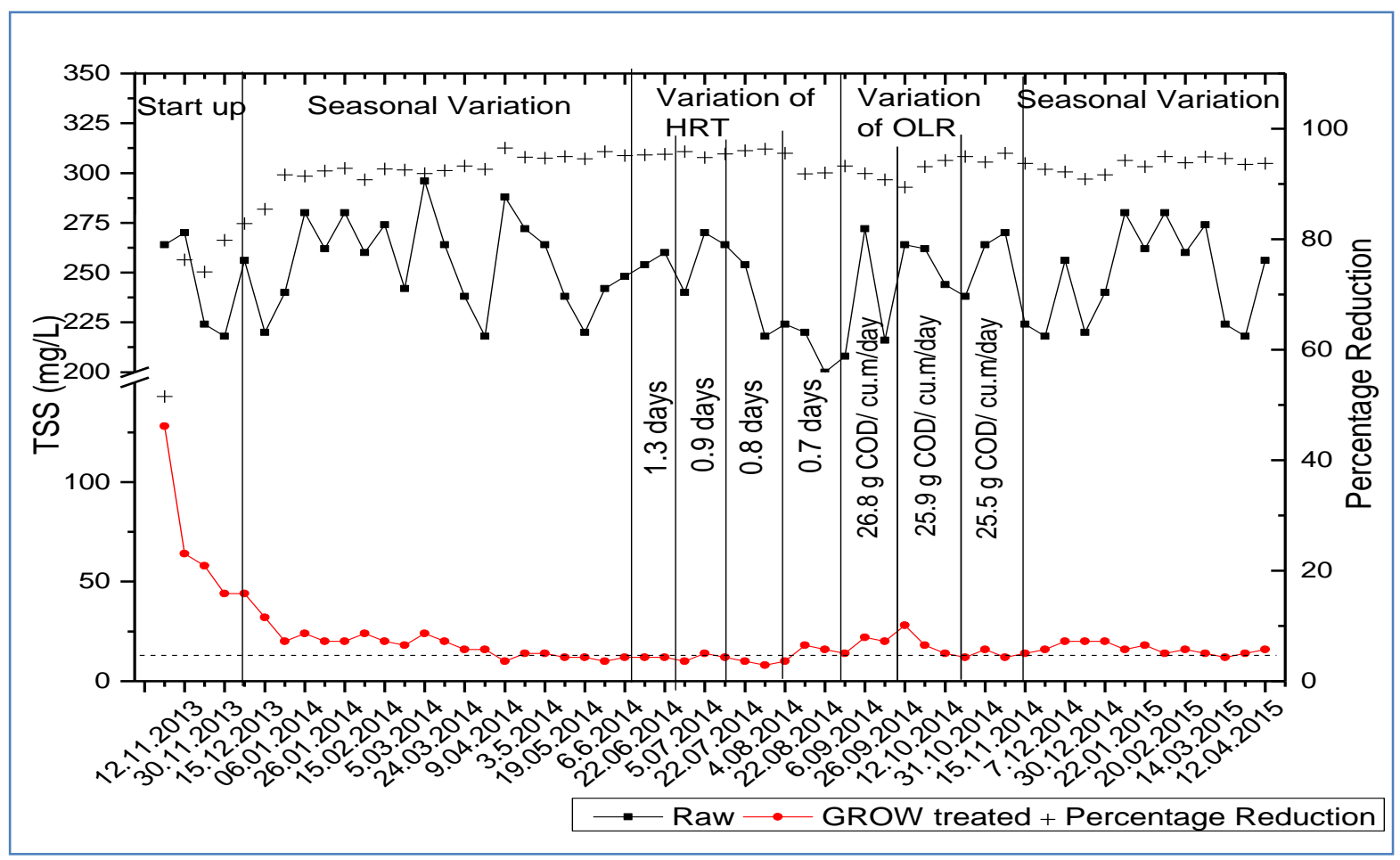

Fig. 4 Performance of GROW systems with respect to the total suspended solids removal during various operational conditions 


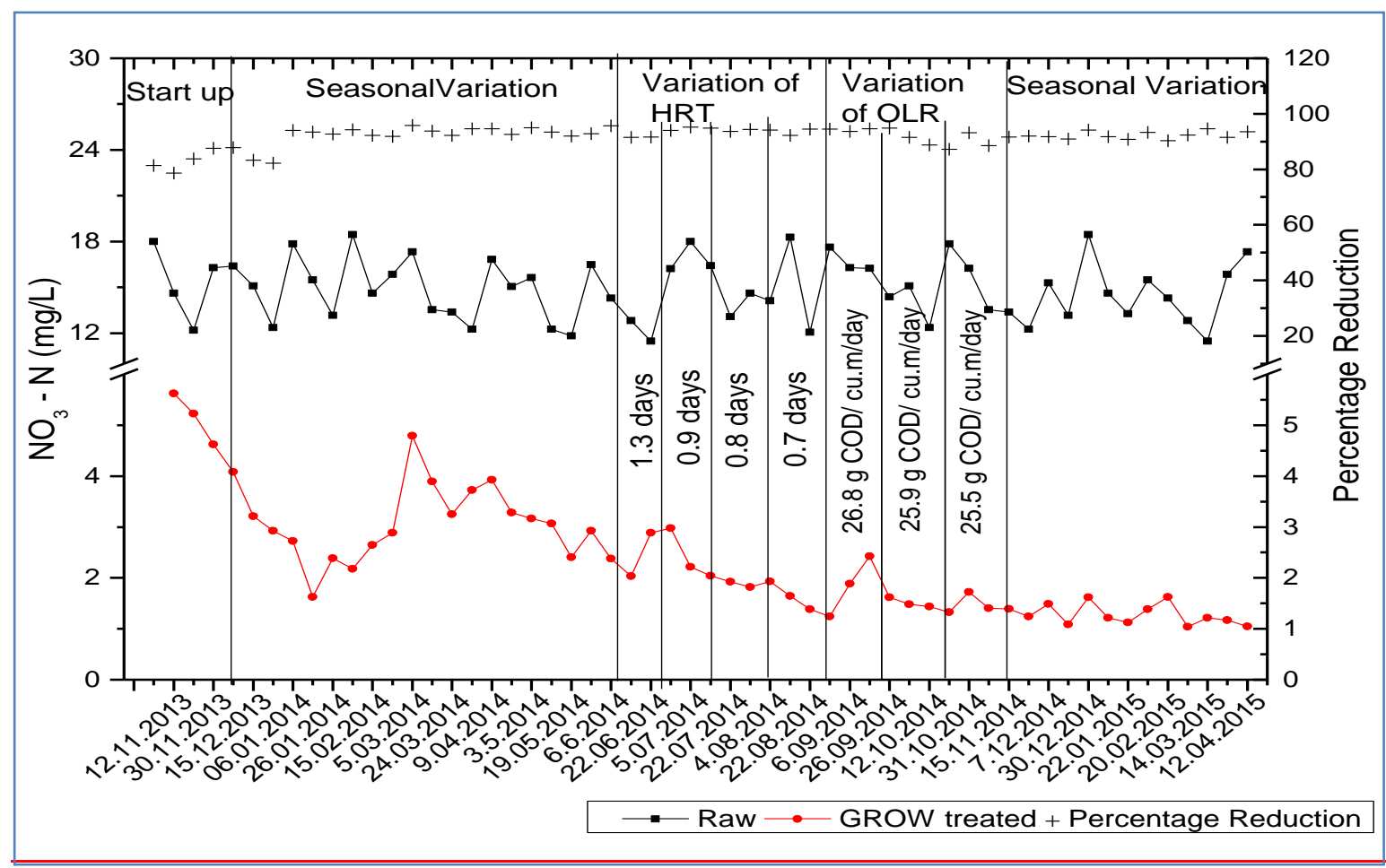

Fig. 5 Performance of GROW systems with respect to nitrate nitrogen removal during various-operational conditions

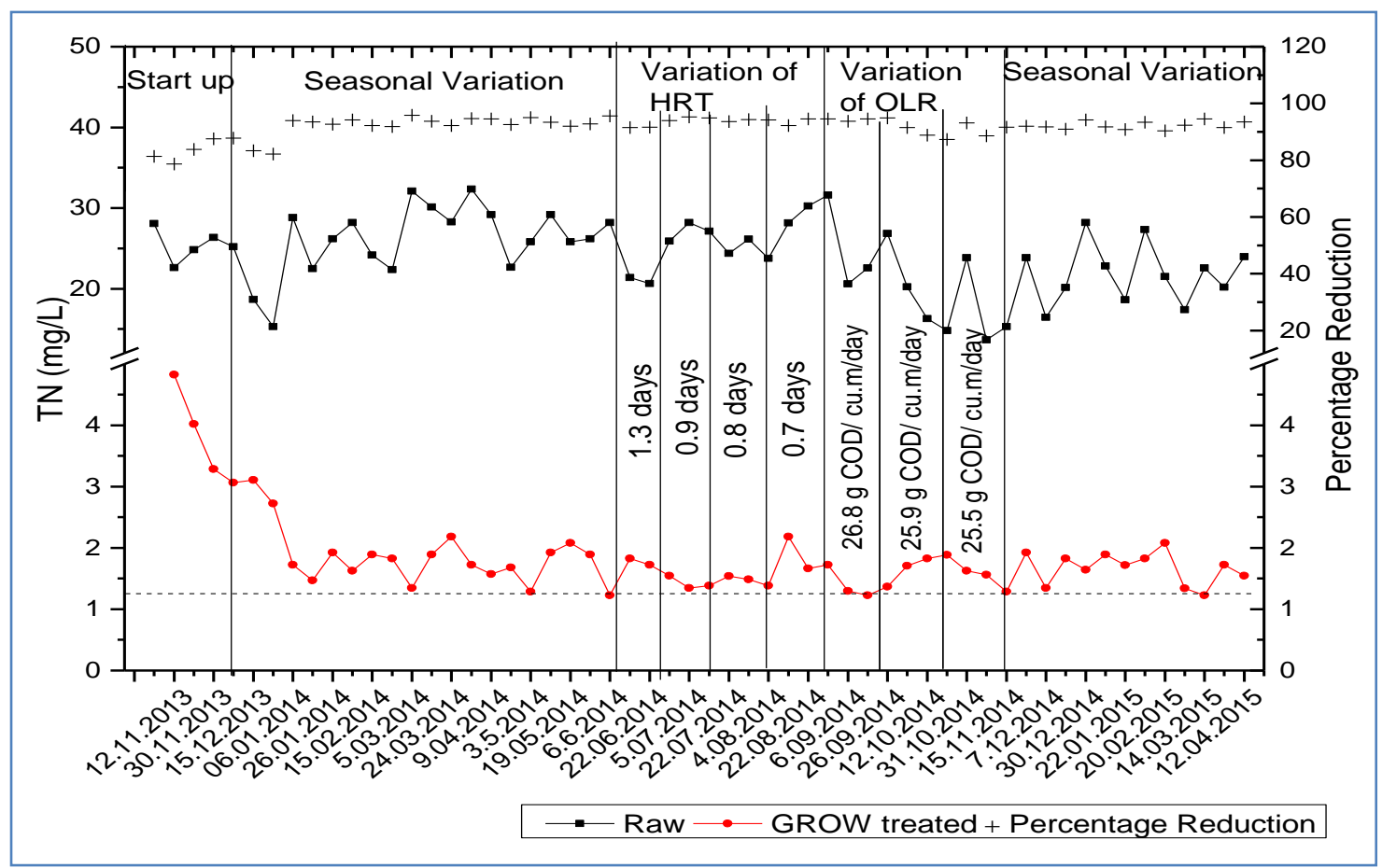

Fig. $6 \underline{5}$ Performance of GROW systems with respect to total nitrogen removal during various operational conditions 


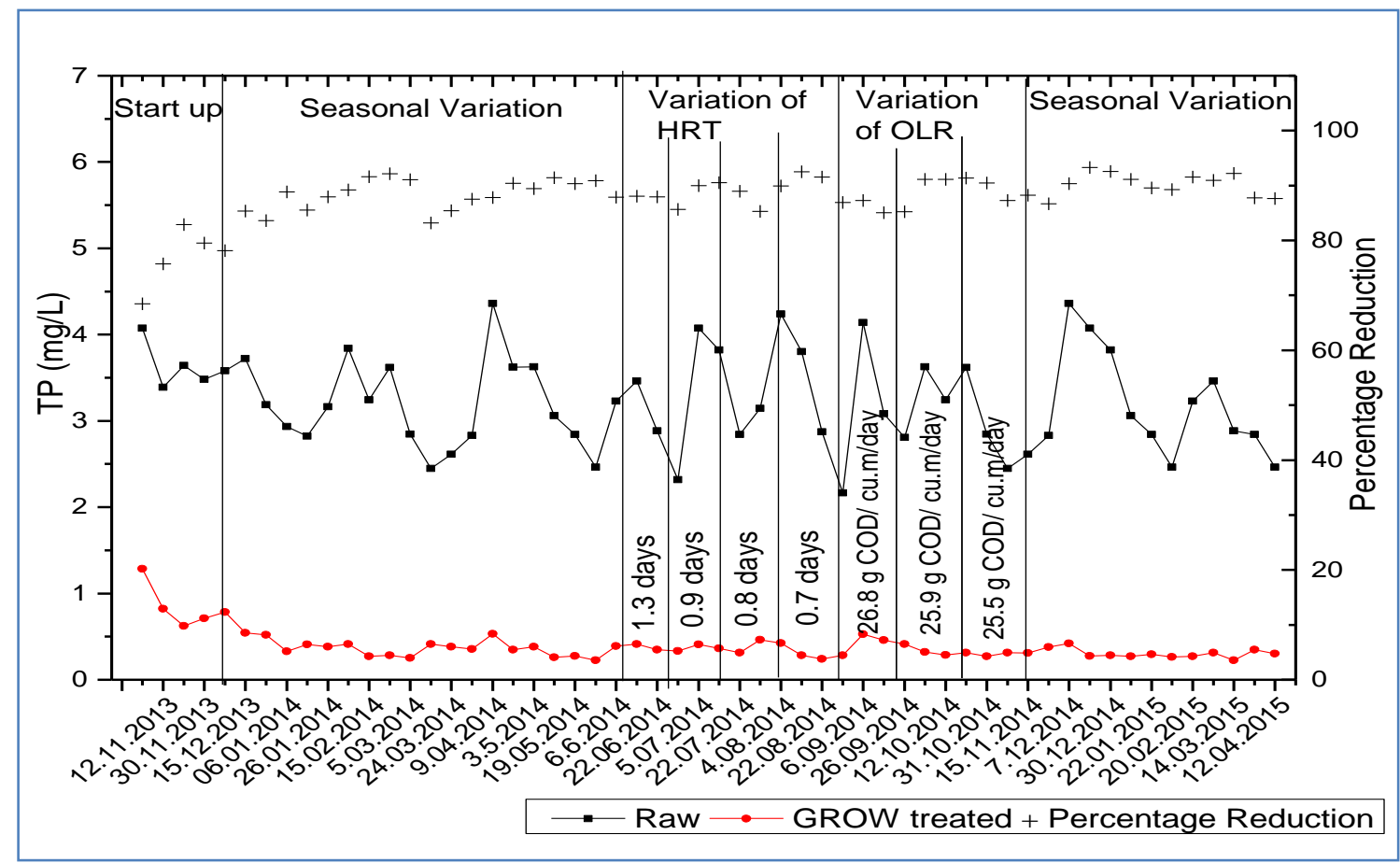

Fig. 7 6 Performance of GROW systems during with respect to total phosphate removal during various operational conditions

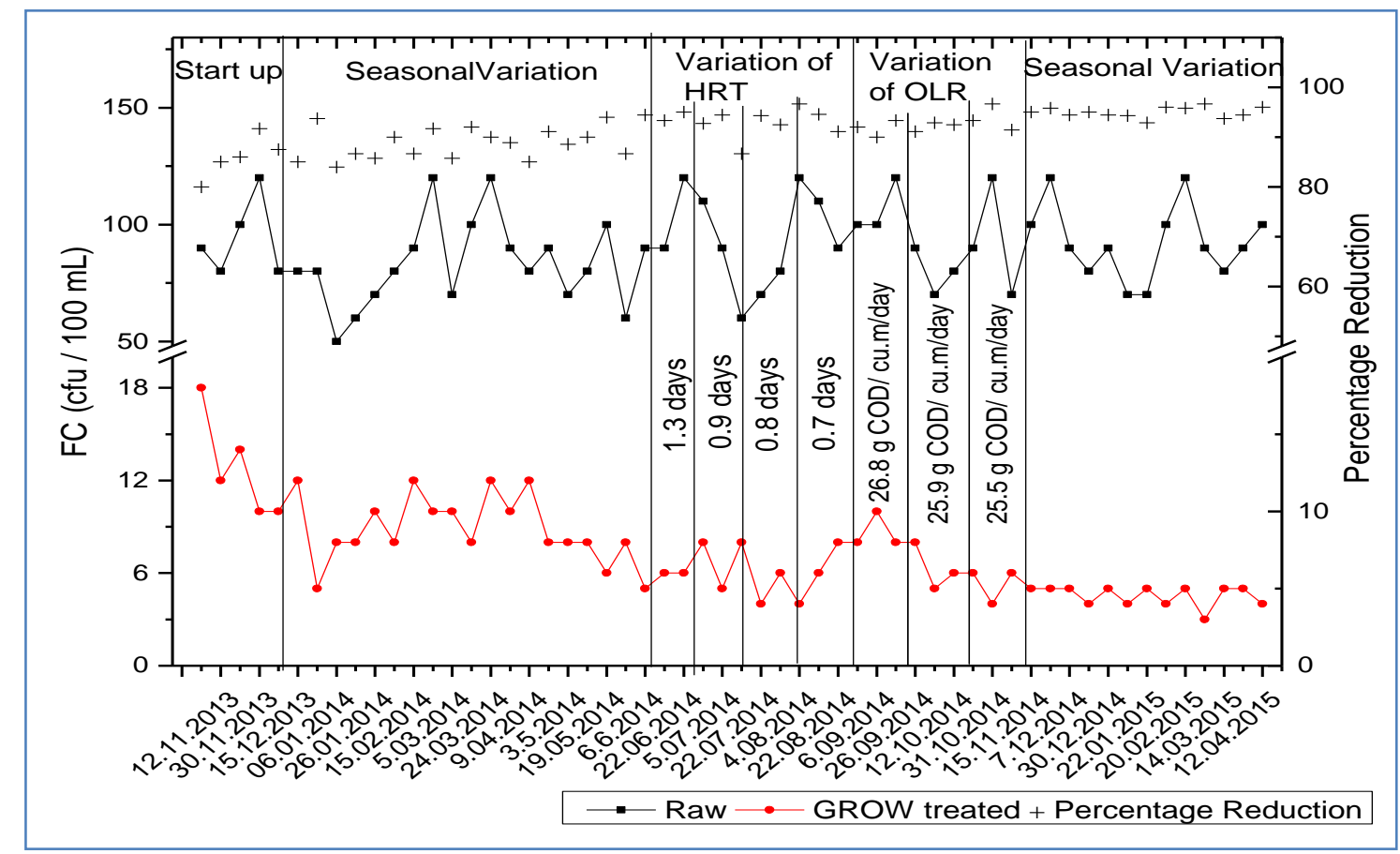

Fig. 78 Performance of GROW with respect to the fecal contamination removal during various operational conditions 


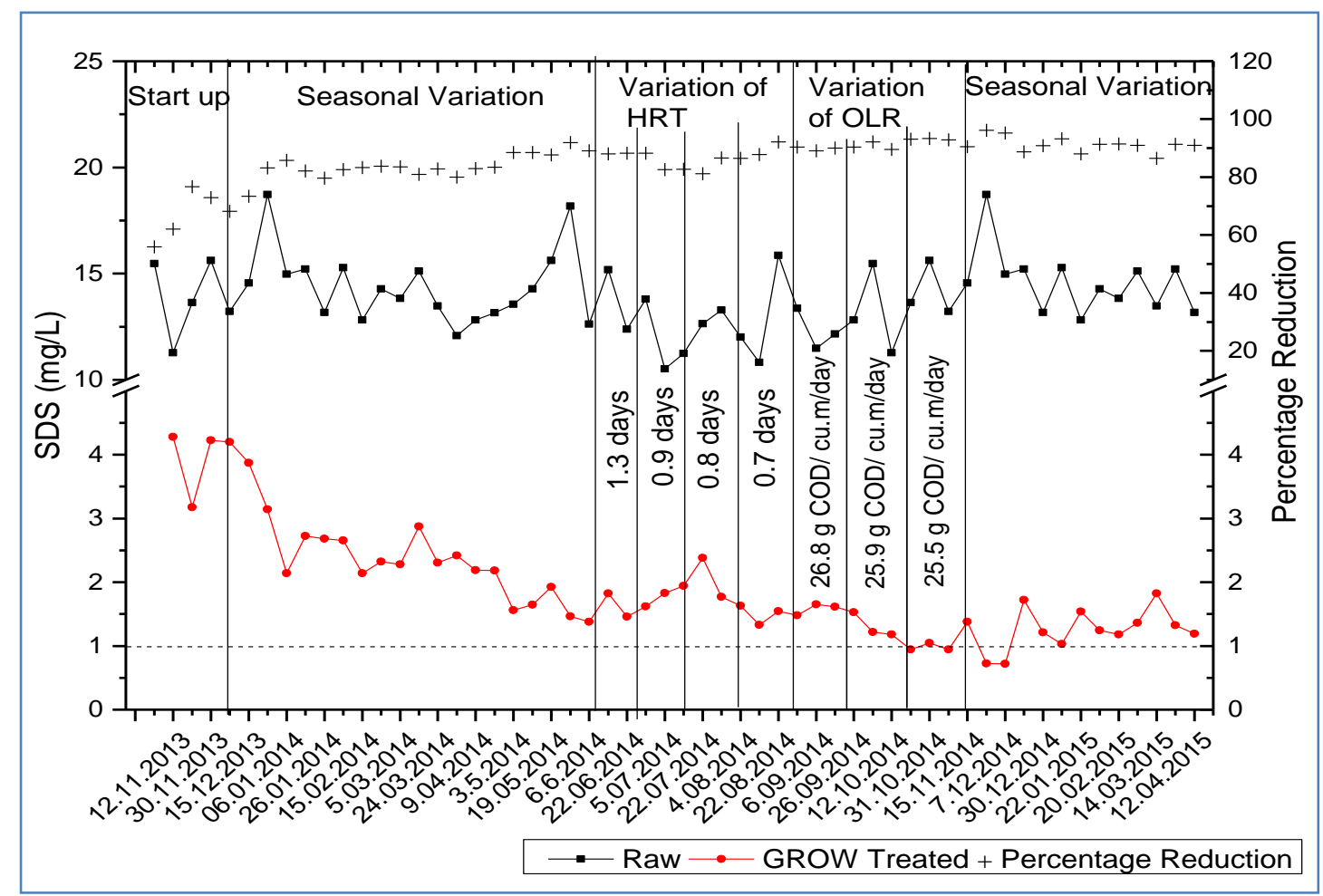

Fig. $\underline{8}^{9}$ Performance of GROW systems with respect to sodium do-decyl sulphate removal during various operational conditions

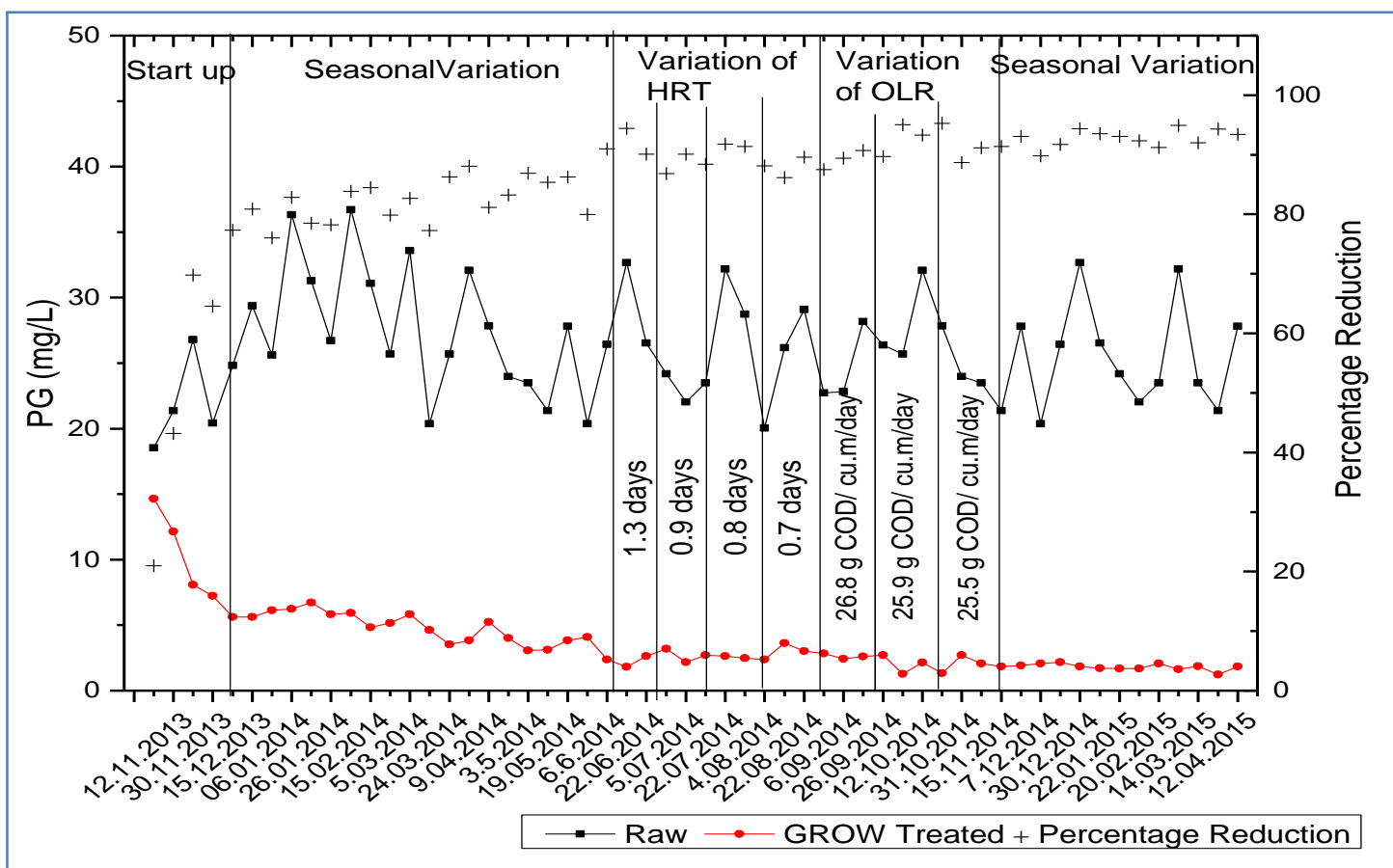

Fig. 910 Performance of GROW systems with respect to propylene glycol removal during various operational conditions 


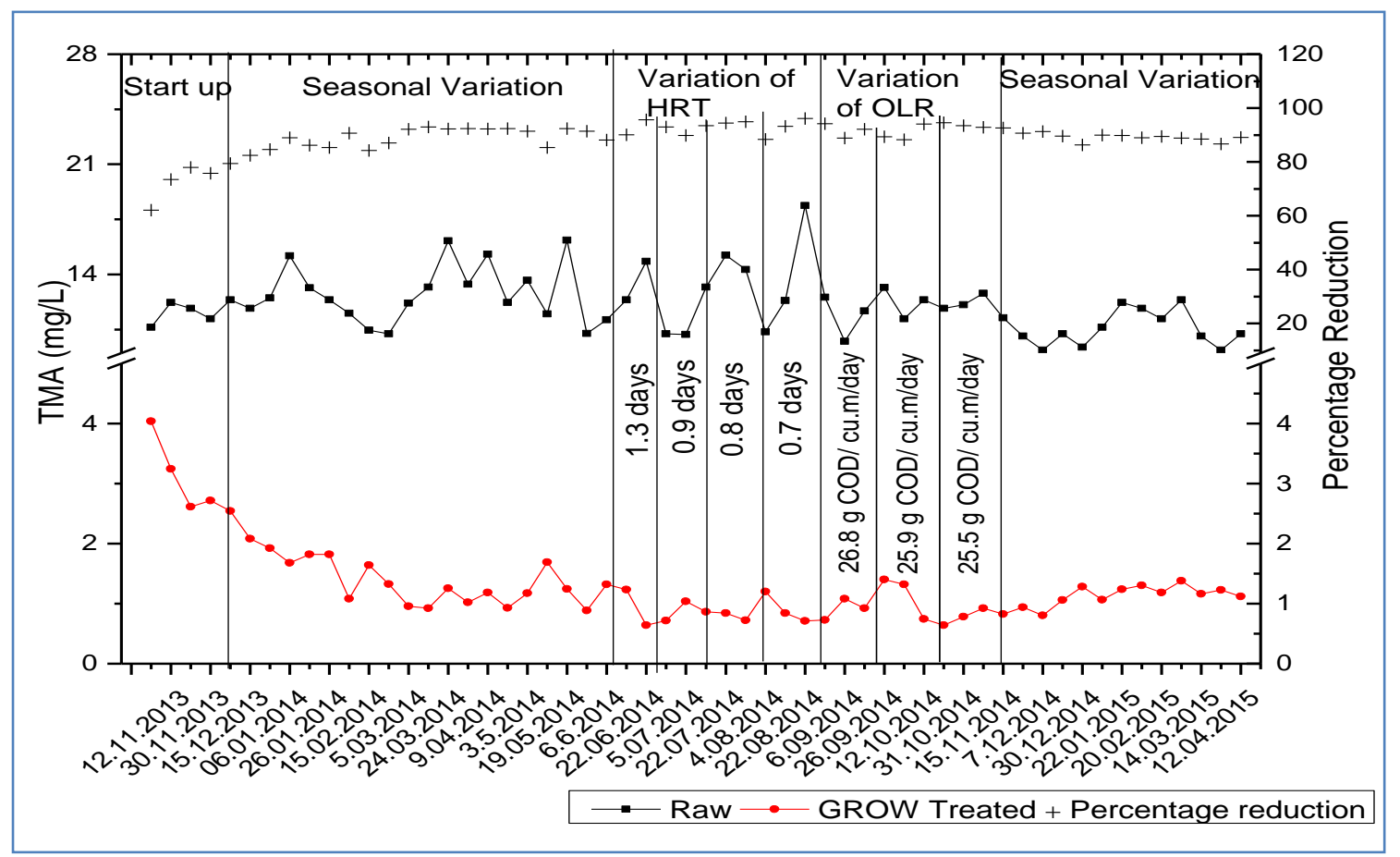

Fig. 11-10 Performance of GROW system with respect to tri-methyl amine removal during various operational conditions 


\section{List of Tables}

Table 1 Operating history for GROW constructed wetland

\begin{tabular}{|c|c|c|c|}
\hline Months of operation & HRT (days) & $\begin{array}{l}\text { HLR (L/ cu. } \\
\text { m/ day) }\end{array}$ & $\underset{\text { day })}{\text { OLR (g COD/ cu. m / }}$ \\
\hline \multicolumn{4}{|c|}{ Start - up phase } \\
\hline November to December, 2013 & 1.09 & 58.3 & 14.0 \\
\hline \multicolumn{4}{|c|}{ Performance Evaluation of GROW system } \\
\hline $\begin{array}{c}\text { Jan to June, } 2014 \text { and Nov - August } \\
2015\end{array}$ & $1.09-1.22$ & 58.3 & 14.0 \\
\hline \multicolumn{4}{|c|}{ Effect of Flow } \\
\hline $3^{\text {rd }}$ and $4^{\text {th }}$ week of July 2014 & $1.3-0.9$ & 58.9 & 12.9 \\
\hline August 2014 & $0.7-0.8$ & 53.1 & 14.9 \\
\hline \multicolumn{4}{|c|}{ Effect of additional organic loading } \\
\hline September-October 2014 & 1.09 & 53.3 & $25.5-26.8$ \\
\hline
\end{tabular}


Table 2 Raw greywater characteristics

\begin{tabular}{|c|c|}
\hline Parameters & Raw Greywater \\
\hline $\mathrm{pH}$ & $7.24-8.34$ \\
\hline $\mathrm{COD}(\mathrm{mg} / \mathrm{L})$ & $216-320$ \\
\hline $\mathrm{BOD}(\mathrm{mg} / \mathrm{L})$ & $68-120$ \\
\hline $\mathrm{TSS}(\mathrm{mg} / \mathrm{L})$ & $240-280$ \\
\hline $\mathrm{TOC}(\mathrm{mg} / \mathrm{L})$ & $23-36.48$ \\
\hline $\mathrm{TN}(\mathrm{mg} / \mathrm{L})$ & $17-28.82$ \\
\hline $\mathrm{NO}_{3}-\mathrm{N}(\mathrm{mg} / \mathrm{L})$ & $12.32-17.84$ \\
\hline $\mathrm{TP}(\mathrm{mg} / \mathrm{L})$ & $2.934-3.84$ \\
\hline $\mathrm{NH}_{4}-\mathrm{N}(\mathrm{mg} / \mathrm{L})$ & $10.28-14.56$ \\
\hline $\mathrm{FC}(\mathrm{CFU} / 100 \mathrm{~mL})$ & $50-120$ \\
\hline $\mathrm{SDS}(\mathrm{mg} / \mathrm{L})$ & $14.99-35.89$ \\
\hline $\mathrm{PG}(\mathrm{mg} / \mathrm{L})$ & $11.58-46.59$ \\
\hline $\mathrm{TMA}(\mathrm{mg} / \mathrm{L})$ & $8.67-15.54$ \\
\hline
\end{tabular}

